<症例報告 $>$

\title{
腹腔動脈造影及び心ェコー図により診断しえた 右心房内発育肝細胞癌の 2 例
}

\begin{tabular}{|c|c|c|c|c|c|c|}
\hline 長崎 & 嘉和 & 江畑 & 浩之 & 佐藤 & 克昭 & 本告 \\
\hline 真島 & 康雄 & 丸山 & 泉 & 平井 & 賢治 & 久保 \\
\hline 谷川 & 久一* & 猪狩 & 民生 & 坂本 & 和義** & \\
\hline
\end{tabular}

要 旨 : 右心房内に腫場の発育が見られた肝細胞癌の 2 例について報告した。選択的腹腔・肝動 脈造影では肝静脈内より下大静脈内を通り右心房内にまで，いわゆる“thread and streaks” sign あるいはそれに類似した所見が特徵であった１例は下大静脈造影蚛よび心ェュー図にて，2 例 々も剖検にて, 肝細胞癌の右心房内腫瘍塞栓を確認した。第 2 例は凝血学的に検討し, 凝固因子 の消費(フィブリノーゲン，血小板）と FDP の上昇を認めた。

索引用語：肝細胞癌腹腔動脈造影（選択的一）心ェュー図腫瘍塞栓（右心房 内一) Budd-Chiari 症候群

\section{はじめに}

肝細胞癌 (以下肝癌) は静脈内に発育し易いが，その 頻度は門脈系に比べ肝静脈系は少ない, ${ }^{1,2,3)}$. 剖検例飞て 肝癌が肝静脈内に，さらには下大静脈内に発育し，右心 房内にまで腫瘍塞栓を認めた報告は見られるが ${ }^{4,5,6)}$, 臨 朱的に腹控動脈造影, 下大静脈造影により生前飞䛦断し た報告は汪とんど見られない”。

われわれは肝静脈，下大静脈内上り逨続性に右心房内 、の腫瘍発育を, 腹腔動脈造影, 下大静脈造影抢よび心 エコー困にて猃断し，剖検にて確認した肝癌の 2 症例に ついて報告する。

\section{症例}

症例 $1:$ 高 $\mathrm{O}=\mathrm{O}$, 24歳, 女性, 仲居

主訴 : 腹部膨隆, 両下肢の浮腫

家族歴：両親が血族結婚の洔か㸩すべことはな ᄂ.

既往歴：特記すべきことはない。

現病歴：昭和51年 12 月 6 日急に両側下肢に浮重が出現 し, 同時に腹部膨隆に気付く . 某医にて肝腫大を指摘さ れ，利尿剮の投与にて下肢の浮盾および腹部膨隆は軽快

\footnotetext{
* 久留米大学第 2 内科

** 久留米大学第 1 病理
}

<受付日54年 8 月 20 日 $>$
したが，肝腫大の精査のため昭和52年 1 月11日当科に入 院した.

入院時現症 : 身長 $139 \mathrm{~cm}$, 体重 $46 \mathrm{~kg}$, 服眕結膜に筫血は 認めないが，眼球結膜に黄㡺を認める。リンパ節は触れ ず，肺肝境界は第 4 肋間で，心肺系に異常は認めない。 腹部では肝を右中鎖骨線上で 6 横指, 正中線上で 4 横指 触知し，辺縁は鈍で，硬く，表面は巴凸が著明であり， 同部に血管雑音を楒取する．䐗の高さより上方に上行性 の腹壁静脈の怒張を認めまた波動を認めた。脾，腎は触 知せず。下肢にのみ軽度の浮腫が見られた。

入院時検查成縜：Table 1 亿示すよらに, 末梢血では軽 度の貧血括よび白血球分類では好中球增多が見られた。

尿では蛋白陽性, ビリルビン陽性であった。肝機能検 査では血清ビリルビン值の上昇, GOT の上昇および GOT/GPT 此恬5.2, Al-P, LAP 打よび $\gamma$-GTP の上昇 が見られた。血清蛋白泳動像ではつルブミンの減少と $\beta$ 扎よび $\gamma$ グロブリンの上昇が見られた。 AFPは3200ng/ $\mathrm{m} l$ であった。腹水の性状は比重 1.022 , 蛋白 $3 \%$, リハ ルタ反応陽性であった．胸部 X線写真では横隔膜の挙上 を認めた。，心電図には異常所見は認めなかった。 ${ }^{198} \mathrm{Au}$ コロイドを使用した肝シンチグラムでは右葉上部を中心 に陰影欠損が見られた。

腹腔, 肝動脈造影 : 右肝動脈は上腸間膜動脈より分枝 
Table 1. Laboratory data on admission

\begin{tabular}{|c|c|c|c|c|c|}
\hline & Case 1 & Case 2 & & Case 1 & Case 2 \\
\hline Peripheral blood: & & & Al-P & 38.0K.A.U. & 26.7 \\
\hline RBC & $342 \times 10^{4}$ & $364 \times 10^{4}$ & ZTT & $11.2 \mathrm{U}$ & 8.8 \\
\hline $\mathrm{Hb}$ & $12.5 \mathrm{~g} / \mathrm{d} l$ & 11.7 & TTT & $2.9 \mathrm{U}$ & 1.5 \\
\hline $\mathrm{Ht}$ & $37.5 \%$ & 36.0 & T. ch. & $268 \mathrm{mg} / \mathrm{d} l$ & 127 \\
\hline WBC & 6800 & 2700 & LAP & $640 \mathrm{U}$ & 459 \\
\hline Stab. & $24 \%$ & 3.5 & Ch-E & $0.31 \Delta \mathrm{PH}$ & 0.39 \\
\hline Seg. & 61 & 59.5 & $\gamma$-GTP & $644 \mathrm{U}$ & 170 \\
\hline Lymph. & 12 & 27.0 & $\mathrm{~T}$. protein & $6.4 \mathrm{~g} / \mathrm{d} l$ & 7.4 \\
\hline Mono. & 3 & 0 & Alb. & $43.1 \%$ & 58.0 \\
\hline Eosin. & 0 & 3.5 & $\alpha_{1}-\mathrm{gl}$ & 4.6 & 5.6 \\
\hline Myelo. & 0 & 4.5 & $\alpha_{2}$-gl. & 8.7 & 8.4 \\
\hline Metamyelo. & 0 & 2.0 & $\beta$-gl. & 14.8 & 6.5 \\
\hline Platelet & $19.8 \times 10^{4}$ & $8.8 \times 10^{4}$ & $\gamma$-gl. & 28.8 & 21.5 \\
\hline Urine: & & & AFP & $3200 \mathrm{ng} / \mathrm{m} l$ & 118 \\
\hline Protein & $(+)$ & $(-)$ & HBs-Ag & $(-)$ & $(+)$ \\
\hline Sugar & $(-)$ & $(-)$ & PT & $65 \%$ & 45 \\
\hline Urobilinogen & $( \pm)$ & $( \pm)$ & HPT & $35 \%$ & 36 \\
\hline Bilirubin & (H) & $(-)$ & BUN & $12.7 \mathrm{mg} / \mathrm{d} l$ & 14.6 \\
\hline Blood chemistry: & & & Creatinin & $0.5 \mathrm{mg} / \mathrm{d} l$ & 1.0 \\
\hline T. bilirubin & $7.0 \mathrm{mg} / \mathrm{d} l$ & 1.9 & $\mathrm{Na}$ & $137 \mathrm{mg} / \mathrm{d} l$ & 143 \\
\hline D. bilirubin & $3.7 \mathrm{mg} / \mathrm{d} l$ & 1.0 & $\mathrm{~K}$ & $3.9 \mathrm{mg} / \mathrm{d} l$ & 3.7 \\
\hline GOT & 134K.U. & 128 & $\mathrm{Cl}$ & $109 \mathrm{mg} / \mathrm{d} l$ & 110 \\
\hline GPT & 26 K.U. & 42 & CRP & $(+)$ & $(+)$ \\
\hline \multirow[t]{5}{*}{ LDH } & $392 \mathbf{U}$ & 475 & RA & $(-)$ & $(-)$ \\
\hline & & & Ascites: & & \\
\hline & & & S.G. & 1.022 & 1.022 \\
\hline & & & Protein & $3 \%$ & 1.8 \\
\hline & & & Rivalta & $(t)$ & $( \pm)$ \\
\hline
\end{tabular}

し，動脈相では肝癌に特有な著明な血管増生像が見られ た.さらに特改的なことは動脈相より毛細管相まで右肝 静脈，下大静脈内さらに右心房内むで刷毛状あるいは手 を束ねたような線条の血管增生像が認められ，腫痬の右 心房内への発育と思われる所見が見られた。 また動脈相 にて肝内門脈右枝より逆行性に門脈系が造影され，上腸 間膜静脈，食道おょび胃静脈瘤む造影され，喢瘍の門脈 系への発育の所見も見られた (Fig. 1). また肝動脈造 影ではさらに明確に右心房内と門脈内への腫湯塞栓を示 す所見が造影されている (Fig. 2).

入院後経過：入院後種々の利尿剤の使用により腹水は 一時的に減少したが，黄㡺は軽快せず，保存的に治療を 行っていたが，昭和52年 3 月10日上り下血があり，フン $€=ア 329_{\gamma} / \mathrm{d} l$ と上昇し，ラクッロース，L-DOPA な
ぞの使用にて，一時的に軽快したが，黄疸於よび腹水の 增加，下血が持続し，尿量が減少し，昭和52年 5 月 22 日 肝不全にて死亡した。

剖検所見：全身に著明な黄底があり，腹水は $5000 \mathrm{~m} l$ 眝留し，小腸拉よび大腸に粘膜下出血をびをん性に認め た。肝は重量1630g で, 腫煬はびまん性にほぼ肝全体を 占め, 左葉の左端と右葉の右端にごくわずが非癌部 が見られた．兩側肺に小豆大の数個の転移巣が見られ た. 腫湯塞栓は著明で, 肝静脈内より下大静脈内を通 り，右心房内にまで見られた (Fig. 3). また門脈系に は門脈本幹を越えて, 脾静脈内拉よび上腸間膜静脈内に まで腫愓塞栓を認めた。組織学的には癌部は索状型で Edmondson II 型の肝細胞癌であり，䀒実質は甲’型肝便 変の像であった。 


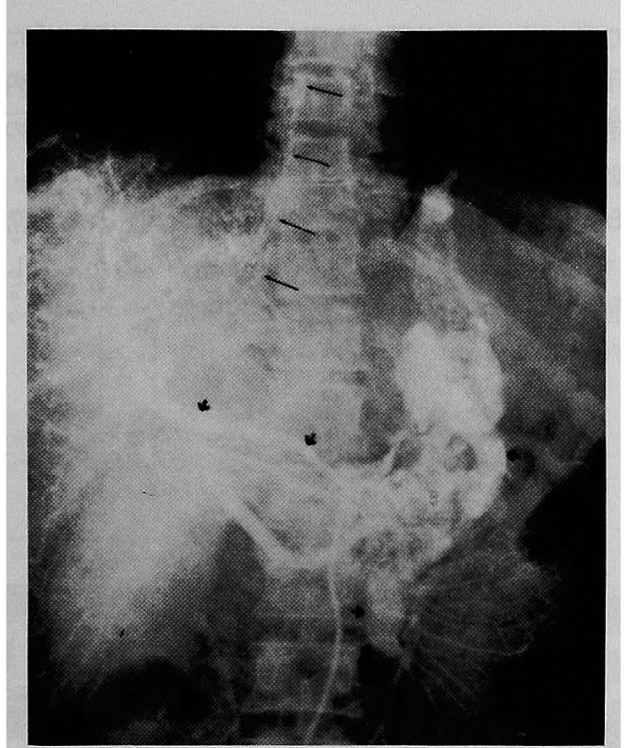

Fig. 1 Superior mesenteric arteriogram of case 1 made at 3 seconds after the start of injection. The right hepatic artery originates from the superior mesenteric artery. Streaks of contrast medium (small arrows) can be seen via the inferior vena cava into the right atrium. Furthermore, the retrograde portal flows (large arrows) of contrast medium into the superior mesenteric and coronary veins are opacified.

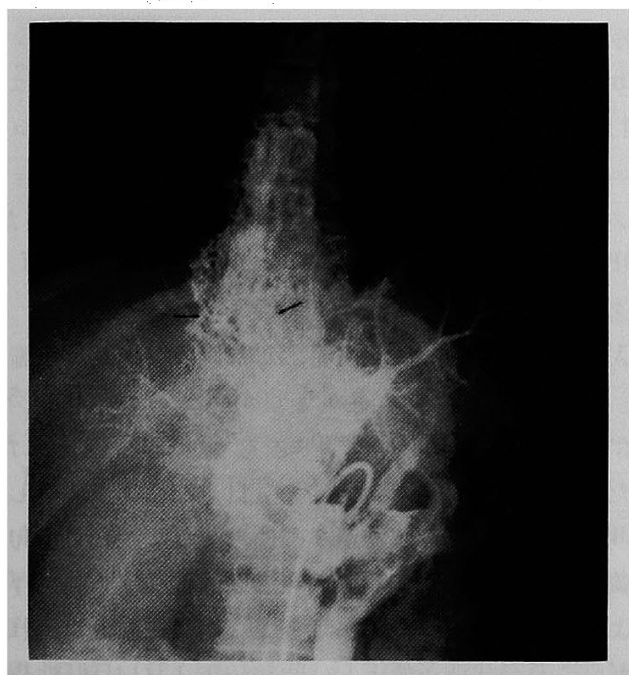

Fig. 2 Hepatic arteriogram (left and middle hepatic arteries) of case 1 made at 3.5 seconds after the start of injection. Several parallel streaks (small arrows) were more apparently visualized than in Fig. 1 and extended into the right atrium. (large arrow).

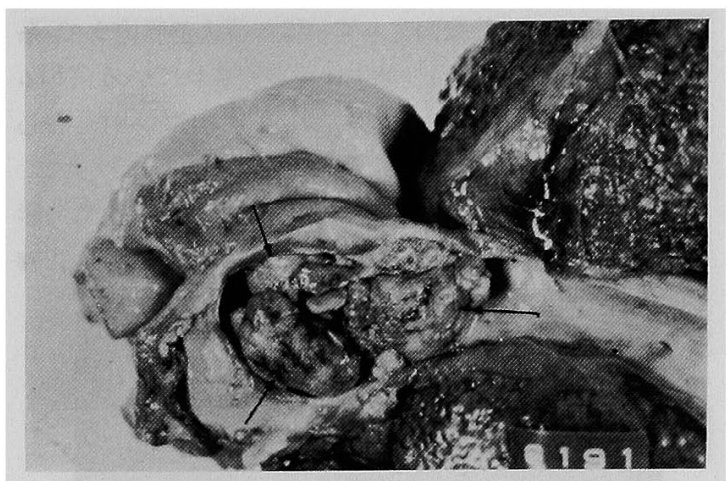

Fig. 3 Gross appearance of the inferior vena cava and right atrium in case 1 . Tumor growth in the right atrium (arrows) was confirmed by autopsy.

症例 $2:$ 永 $\bigcirc$ 利 $\bigcirc, 40$ 歳, 男性, 運転手 主訴 : 腰痛, 両下肢の浮腫

家族歴：祖父が脳卒中にて死亡した。

既往歴：小学生の時気管支喘息に䍜患した.

現病歴：生来健康であったが，昭和52年 8 月下旬より 右季肋部痛が出現し，心裔部の膨隆に気付いた１0月20 日頃より腰痛が出現し，10月28日より両下肢に浖腫を認 め, 某医を受診し，肝細胞癌叔よび肺転移の嶷い《て， 11月14日当科に入院した.

入院時現症 : 眼球結膜に軽度の黄疸を認めるが，畕血 所見は見られない，リンパ節は触れず，肺肝境界は第 3 肋間で，心肺系には異常は認めない，腹部では肝を右中 鎖骨線上で 2 横指，正中線上で 5 横指触知し，表面は凹 円が著明で，硬度はやや便く，圧痛を認めた，䋃径部よ り上行性の腹壁静脈の怒張が見られ，腹水および両下肢 の浮腫を認めた。脾和よび腎は触知しなかった。

入院時検查成績 : Table 1 に示すように，白血球の減 少と分類にて幼若球の出現が見られた．脾機能検査では GOT の上昇, GOT/GPT 比の增加, Al-P, $\gamma$-GTP, LAP, $\mathrm{LDH}$ の上皏が見られ，AFP $118 \mathrm{ng} / \mathrm{m} l$, HBs-Ag は陽性 であった，腹水の性状は比重 1.022 ，蛋白 $1.8 \%$ ，リバル タ反応は豖陽性だった.胸部X線写真では両肺野に3個 の円形異常陰影と右横隔膜の挙上が見られた。 ${ }^{198} \mathrm{Au}=$ ロイドによる肝シンチグラムでは右葉に大きな陰影欠損 衣認めた．肝ェコーグラムにても右葉に大きな異常ェコ 一があり，内部は low density であった。

腹腔動脈造影 : 動脈相にて右肝動脈の領域に周辺部は 腫瘍血管の増生があり,中心部は壊死のために hypovascularである大きな腫榴が造影された。ささらに動脈相より 
毛細管相まで, 膒竫脈内より連続性に下大静脈内まで, 系 を束ねた様な線条の血管増生像が造影されている（Fig. 4). しかし腫瘤により下大静脈が左方に圧排され，右心 房内への腫瘍の発育を示す所見ははっきりしなかった。

下大静脈造影 : 大腿静脈よりカテーテルを挿入し造影 を行うと，肝静脈の下大静脈流入部位と思われる第12胸

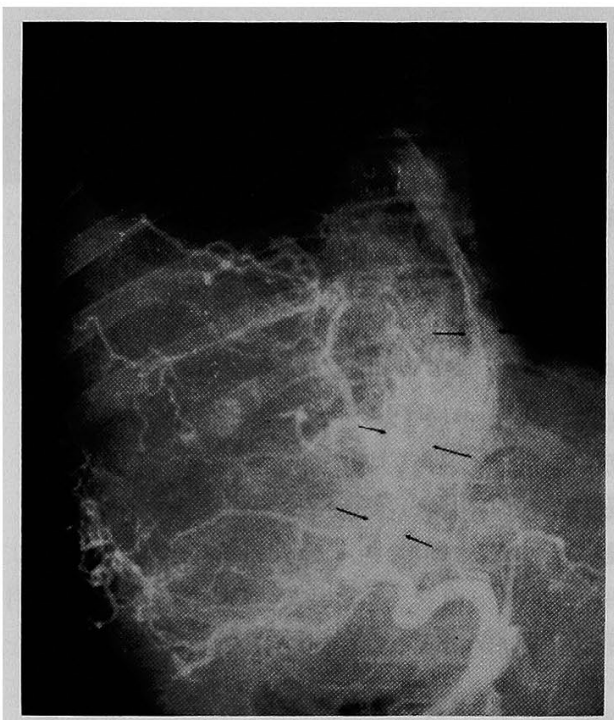

Fig. 4 Celiac arteriogram of case 2 taken at 3.5 seconds demonstrates a tumor thrombus (arrows) growing toward the right atrium.

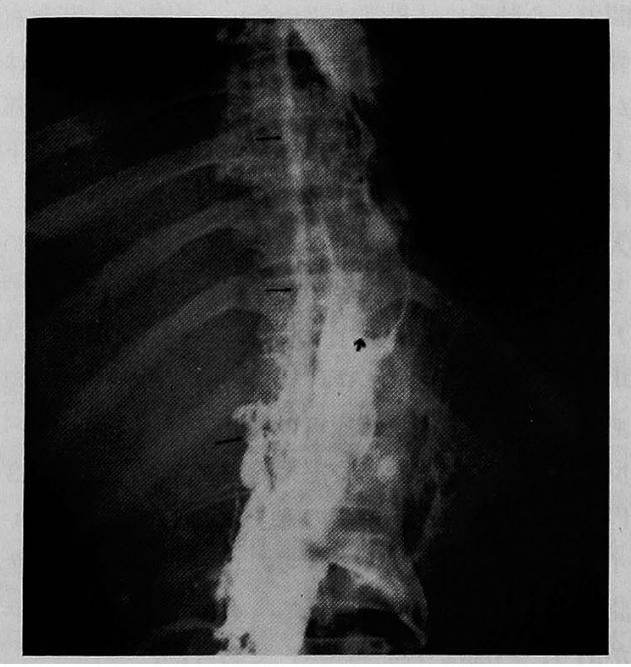

Fig. 5 Inferior vena cavogram of case 2 demonstrates occlusion of the inferior vena cava (large arrow) by tumor extension. The contrast medium drains through the azygos system (small arrows)
椎の高さで，下大静脈に陰影欠損を認めた（Fig. 5). これは腹腔動脈造影で証明した肝細胞癌の下大静脈内へ の発育の下端と一致していた。さらに半奇静脈などの側 副血行路が造影された。

心エコ一図：右心房内に層状の腫瘍と思われる異常な エコーが認められ，拻張期には右心室内へもかん入し， 可動性の見られる腫湢と思われる異常なエコーだった (Fig. 6).

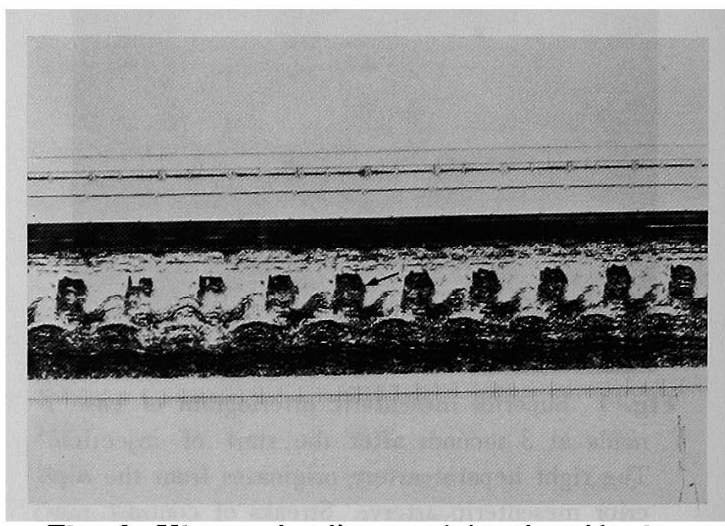

Fig. 6 Ultrasoundcardiogram of the tricuspid valve of case 2 demonstrates the abnormal echoes (arrow) moving in diastole from the right atrium to the right ventricle.

凝血学的検討：症例 2 の凝固線溶系の推移を Fig. 7 に示した．入院時血小板は5.4万，フィブリノーゲノは $20 \mathrm{tm} g / \mathrm{d} l$ であったが，両者とも溸隇しその末期には各 各 1.8 万， $40 \mathrm{mg} / \mathrm{d} l$ と著減した。入院 2 カ月後のトロン ボェラストグラムは Fig. 8のごとく，血小板とフィブ リノーゲンの低下による ma の縮小が特徽的であった。 FDP は入院時の $5 \mu \mathrm{J} / \mathrm{m} l$ から栨第に增加 $20 \mu \mathrm{g} / \mathrm{m} l$ ま で達した。

入院後経過：炤和52年11月22日に腹控動脈造影を施行 乙, 肝動脈内に Mitemycin C 30mg, 5-Fluorouracil 500 $\mathrm{mg}$, Cytocine arabinoside 40mg t one shot 注入した. また OK-432（ピシバニール）を11月25日より使用し， 2.0K.E. 維持量として，過 2 回使用したが，12月中旬よ り黄瘨の增強，はばたき振戦が出現し，腹水，下肢の浮腫 怙よび上行性の静脈怒張が増強し，出血傾向も現われ， しだい意識状蕉が低下し，昭和53年 2 月14日肝性昏睡 にて死亡した.

剖検所見：全身に著明な黄疸を認め，腹水は血性であ

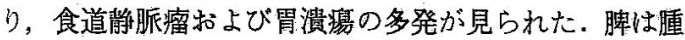

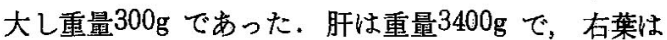




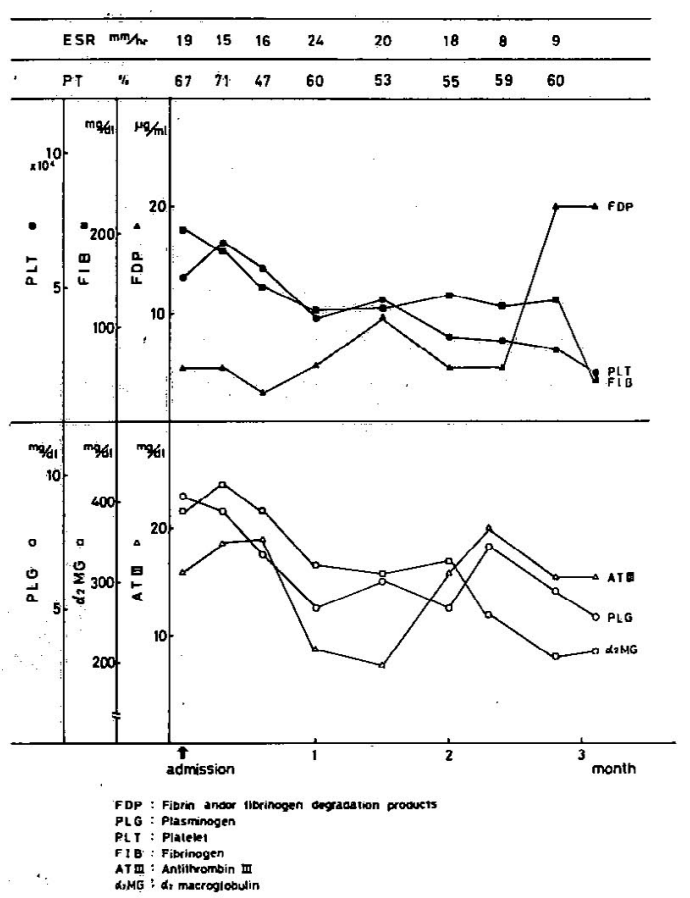

Fig. 7 Changes of coagulofibrinolytic examination of case 2 . Fibrinogen and platelets were markedly decreased in the terminal stage.

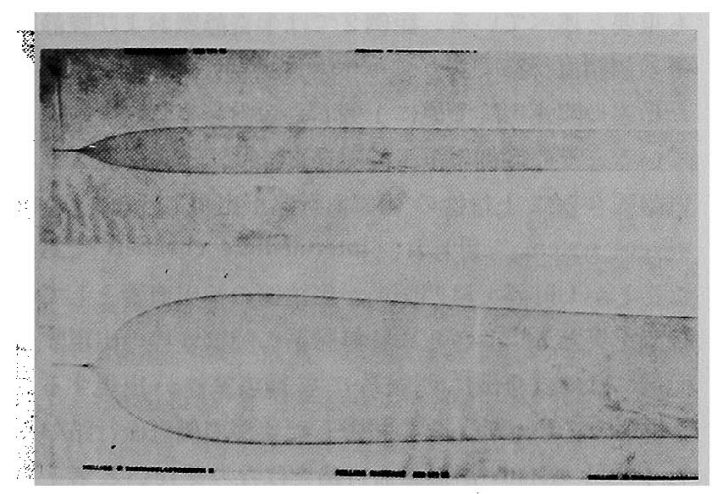

Fig. 8 Thromboelastogram of case 2 at two months after admission. Decreased ma was noted $(r=9$ $\min . \mathrm{k}=25 \mathrm{~min} . \mathrm{ma}=20 \mathrm{~mm}$ ).

注全体が腫瘍でしめられ，一部には被膜の形成が見ら れ, 左葉には肝内転移を認め, 中島・坂本の肉眼分類 ${ }^{8)}$ では混合型 (N型)であった。転移は血行性飞雨側肺 に, リンパ行栍に膵頭部周围リンパ節に，浸潤性火棈隔 膜に見られた，腫演塞栓は門脈内之ともに，肝静脈， 下大静脈内を経て，右心房拉よび右心室内にも見られ

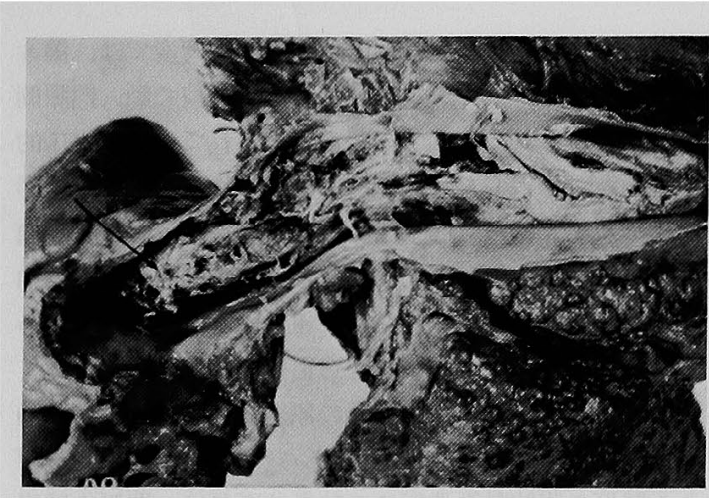

Fig. 9 Gross appearance of the inferior vena cava and right atrium in case 2. Tumor growth in the right atrium (arrow) was confirmed by autopsy.

た (Fig. 9). 組織学的には癌部は trabecular type で Edmondson III型の肝細胞癌で, 非癌部 は乙型肝硬変の 像であった。

\section{考案}

Budd-Chiari 症候群は肝静脈の閉塞によるものを呼ん でいるが, 原因のはっきりしない原発性のbのと，他の はっきりした原因に付随しておこる続発性の二つに分け て考えられる、続発性のもので最も頻度の多いのは腫瘍 によるるのであり，その中で肝癌によるものが最も多く 重要である ${ }^{9}$. この肝癌に合併する Budd-Chiari 症候群 は腫瘍の静脈内発育によるものである.従って腫瘍の発 育端は下大静脈内に，更にはなはだしきは右心房内にま で及び，この様な症例です広義に Budd-Chiari 症候群と 呼ばれている事が多い。

肝癌は静脈系とくに門脈内へ発育する頻度は高いが， 肝静脈内への頻度は閒脈内に比べ低いと言われている。 教室の下川ら 1 は113例の肝癌剖倹例を検討し, 門脈内発 育を80例 (70.8\%) に, 肝静脈内発育を15例 (13.3\%) に 認內, 前者が後者の約5.3倍と報告している.Edmondson ${ }^{2)}$ の65例の肝癌剖検例によると, 門脈内に22例 (33.8\%), 肝静脈内に 11 例 $(16.9 \%)$ の腫瘍塞栓を認め, このうち 7 例 $(10.8 \%)$ が下大静脈内 まで，1 例 $(1.5 \%)$ が右 心房内まで達していた，肝㾔の右心房内発育は徳田の 剖倹例による検討では ${ }^{10)} ， 233$ 例中10例 $(4.29 \%)$ であ り，昭和40年より50年まで11年間の全国剖検輯報に記載 された肝癌剖検例7145例のうち右心房内腫瘍転移または 挝瘍塞栓の記載は48例 $(0.67 \%)$ であった。このよらに 肝癌が肝静脈系に比校して門脈系へ発育し易い原因とし て, 門脈系が癌結節の輸出血管としての役割を果たすた 
め11)，打よび肝癌に高頻度に合併する肝硬変では，第 8 次の血管枝以下，多くは第10１2次の分枝で動，間脈閒

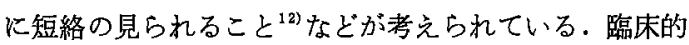
にも私達が報告したように, 肝癌154例の腹腔動脈造影 による検討では，問脈内発育は87例 $(56 \%)$ ，肝静脈内 発育は 9 例 $(6 \%)$ であった ${ }^{13)}$.さらに肝癌の右心房内 発育を腹空動脈造影で証明した報告は少なく，Gregg ら ”が腹腔動脈造影と下大静脈造影で 1 例報告している。 教室での肝癌の右心房内発育の頻度は，198例に腹腔動 脈造影を行い2 例 $(1.0 \%)$ であった，右心房内に発育 した肝癌の腹沿動脈造影での特徽的所見は，門脈内腫浧 塞栓に認められる “thread and streaks" sign'14) と類似し ている.つまり Fig. 1，2，4で示したように，動脈相早 期より毛細管相，ときとは静脈相をで，刷毛状あるいは 系を束悋たような平行な線条の血管增生像が肝静脈内よ り下大静脈内を通り，右心房内にまで連続性に見られる ことである.この血管增生像は病理学的にも動脈に由来 することが確かめられている ${ }^{11)}$ 。 また Fig. 5 に示した 上うに，大胀静脈よりカテーテルを插入し，下大静脈造 影を行竞ば，肝静脈の下大静脈合流部に陰影欠損を認め ることより診断を確実に出来る。ささらに上肢よりカテー テルを上大筝脈より右心房近くまで挿入し，造影を行う ことも有用であると思われる。しかし症例 2 は腹腔動脈 造影および下大静脈造影では肝癌が肝静脈内上り下大静 脈内をで発育していることは診断しえたが，右心房内へ の発育忤認出来なかった。肝癌の右心房内への発育の 有無は心ェコー図で検討した。 心ェコー図は, 被験者に なんら苦痛を与えず，非侵襲的に，心臟腫煌の正確な診 断が行なえる

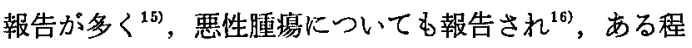
度両者の鑑別点についての記載もある ${ }^{17}$. しかし肝癌の 右心房内発育を心ェコー図で診断した報告は，調べた範 囲では見い出せなかった. 症例 2 の心ェュー図で示した よ5に，右心房内に層状の腫場エコーを指摘しえた。す で報告したように ${ }^{18)}$ ，腹腔動脈造影では腫煌塞栓の肝 静脈内㧍よび下大静脈内の心缄側の端は不明膫であるこ とが多く，腫愓の発青が右心房内にまで及んでいるかど らかの診断は，心ェニー図が有效だった。ささらに加登

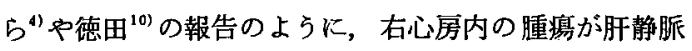
内抢上び下大静脈内の腫瘍と連続性を認めない症例に は，心エュー図はさらに有效と思われる。このように腹 热動脈造影，下大静脈造影拈よび心ェコー図により肝癌 の右心房内発育による続発性の Budd-Chiari症候群は正
確に猃断出来るが, 生前に診断し，経過を観察した臨床 報告が少ないのは, 肝癌そのものに基つく症状と, 合併 する肝硬変の症状とが重複して診断を困難にしているた めと思われる. 右心房内に発育した肝癌の症状として は，加登ら"などの報告のように，体位変換により発作 的炕増悪する呼吸困難, 心音の異常, 心雑音, 急激な血 圧の下降, チアノーゼの出現などの症状があげられてい る.この症例は右心房内の腫瘍と肝静脈, 下大静脈内の 腫瘍との連続性がなかった。私達の症例で恃肝静脈内上 り右心房内をで腫掦が連続し，上記のような症状は示さ なかったと思われる。しかし注意すべき症状としては下 肢に著明な浮腫, 上行性の腹壁静脈の怒張, 難治性の腹 水扣よび肝腫大であり，普通の肝癌と比較し，これらの 程度が強いようであった．また腹水の性状は症例 1，2 はそれぞれ蛋白は $3 \% ， 1.8 \%$ と普通の肝癌と比較し高 く，広義の Budd-Chiari 症候群である右心房内へ腫湯の 発育した肝癌の特徵の 1 つと考光られる.

肝静脈内より下大静脈内さらに右心房内まで腫瘍塞拴 で充たされた肝癌の血行動態，すなわち側副血行路は明 らかではない，Ferris ${ }^{19)}$ らは下大静脈を結禁後の側副血 行路を下大静脈造影にて 4 型に分類している.つまり central channels, intermediate channels, portal system, superficial routes の4型であり, central channels が最 も重要と述べている.症例 2 では半奇静脈就よび腰静脈 系の側副血行路であり， central channelsであった。ま た私達の関連病院で他に 1 例右心房内発育肝癌を経験し ている. その症例の下大静脈造影では，下大静脈より左 腎静脈さらに上行性の側副血行路が出現し, left renalazygos system と思われ，intermediate channels であっ た.しかし肝癌では門脈系が癌結節の輸出血管としての 役割を果たし ${ }^{11)}$ ，さらに肝静脈系に腫湯塞栓の出現する 症例飞はほぼ全例に門脈系にも腫場塞栓が出現するこ $と^{10)}$ 上り, Ferris ${ }^{19)}$ らの報告した 4 型の側副血行路のう ち portal system が側副血行路とはなりえないと考えら れた.

肝癌が右心房内にまで腫煌塞栓を形成した症例とその 他の肝癌の㠜血学的な相違は核とんど 報告されていな い. 当教室の肝㴦40例に拊ける入院時の血小板とフィブ リノーケ゚ンの平均値は各々 12.0 万扩よび252mg/d $l$ であ り，その末期の血小板については9.4万であった。また one shot 直後 ( $1-3$ 週間) には血小板の減少を認める が, 末期では one shot 群と制癌剤非使用群との血小板 数には有意差を認めなかった。症例 2 の血小板とフィブ 
リノーゲンの著減は one shot 直後のみでなく持続的で あり,肝癌としては一般的な值ではない，FDP は增加し， serial thrombin time は34.7秒と延長傾向を示し，第VII 因子 $130 \%$,第VII因子 $40 \%$ といずれも肝癌としては低值を とっている. またプラスミノーゲンと $\alpha_{2} マ$ マクグロブ リンも経過とともK減少しているが，肝の合成能の低下 を考慮にいれると，線溶九進はあっても軽度と言わざる を得ない，従って症例 2 の凝固線溶検查の変動はDIC と 言うより，腫瘍塞栓が静脈系へ広範に浸潤した事による 局所的(下大静脈・右心房)な凝固拉よび線溶九進の存在 が推測された. 事実, 腫瘍塞栓が下大静脈内まで達した 肝癌では FDP が高値を示す症例が少なくなかっだの).

$$
\text { まとめ }
$$

選択的腹㒄就よび肝動脈造影にて，2 例の肝細胞癌に 右心房内腫瘍塞栓を示す所見を認めた．その特徽的な所 見は糸を束ねた様な線条の血管增生像が，動脈相より毛 細管相まで, 肝静脈内, 下大静脈内さらに右心房内に まで連続性に造影されることで，いわゆる“thread and streaks"sign に類似していた.さらに1例は下大静脈造 影および心エコー図により，2 例とも剖検により肝細胞 癌の右心房内発育を確認した。 また1例は凝血学的に検 討し，凝固因子の消費（フィブリノーゲン，血小板）と FDP の上昇を認めた.

本論文の要旨は第31回日本消化器病学会九州地方会 （1978，6月）にて報告した。

\section{文 献}

1）下川泰他：原発珄肝癌に関する研究，第 3 報，肝細胞癌の中島・奥田肉眼分類とその瀶床 病理学的特徵. 肝臓, $16: 752,1975$.

2) Edmondson, H.A. \& Steiner, P.E.: Primary carcinoma of the liver. A study of 100 cases among 48,900 necropsies. Cancer, 7: 462, 1954.

3) 璘地浩吉他：原発性肝癌と Budd-Chiari 症候群 について. 肝臓, $6: 337,1965$.

4) 加登康洋他：右房内に尰湟による巨大球状血栓 を生じた肝癌の 1 例. 内科, $28: 349,1971$.

5) 北村次男他 : 赤血球堌多, Budd-Chiari 症侯群 および低血糖を呈した原発性肝癌の 1 例. 肝 藏, $9: 392,1968$.

6) 久保田 智他：腫瘄栓塞により Budd-Chiari 症 候群を呈した原発性肝癌の1剖检例. 内科,
29:553, 1972.

7) Gregg, F.P. et al.: Arteriographic demonstration of intravenous tumor extension. Am. J. Roentgenol., 123: 100, 1975.

8) Nakashima, T. \& Sakamoto, K.: A study of hepatocellular carcinoma among japanese from the point of view of morpho-developmental pathology. Gross anatomical types classified in its relation to capsule formation. The Kurume Med. J., 24: S43, 1977.

9) 高田 昭他：Budd-Chiari 症候群一主として secondary Budd-Chiari 症侯群について一. 最 新医学, $24: 1055,1969$.

10) 徳田恵子：原発性肝癌の病理形態学的研究一肝 細胞癌に和ける右心房内 tumor thrombus を伴 弓例を中心に一. 久留米医学会雑誌, $41 ： 1044$, 1978.

11）倉富晋太郎：肝細胞癌の病理形態学的研究，血 管構築よりみた進行性肝癌並びに血管内腫瘍塞 栓の病理. 肝臓, $17: 517,1976$.

12）三宅 仁他：血管構造よりみた 肝疾患の 病理. 内科, $11: 604,1963$.

13）長崎嘉和：腹腔動脈造影による肝細胞癌の動門 脈吻合に関する研究. 肝缄, 20：180, 1979.

14) Okuda, K. et al.: Demonstration of growing casts of hepatocellular carcinoma in the portal vein by celiac angiography: The thread and streaks sign. Radiology, 117: 303, 1975.

15）平田経雄他：心臓腫鈞 $エ ェ コ ー$ 診断. 内科, $36: 786,1975$.

16）仁村泰治他：右心内腫瘍の超音波診断. 日本超 音波医学会第25回講演論文集, 75, 1974.

17) 吉川純一：臨休心ェュー図，1版，金原出版， 東京, 1977, p. 158.

18) Okuda, K. et al.: Angiographic demonstration of growth of hepatocellular carcinoma in the hepatic vein and inferior vena cava. Radiology, 124: 33, 1977.

19) Ferris, E.J. et al.: The inferior vena cava after ligation and plication: A study of collateral routes. Radiology, 89: 1, 1967.

20）江烟浩之他：肝硬変症ならびに原発性肝癌に和 ける凝固線溶学的檢討. 日消誌，投稿中. 
Two cases of hepatocellular carcinoma with tumor growth in the right atrium demonstrated by selective celiac arteriography and ultrasoundcardiography

\author{
Yoshikazu Nagasaki, Hiroyuki Ebata, Katsuaki Sato, Hitoshi Motoori, \\ Yasuo Majtma, Izumi Maruyama, Kenji Hirai, Yasuhiko Kubo, \\ Kyuichi TaniKawa*, Tamio IKari and \\ Kazuyoshi Sакамото**
}

Two cases of hepatocellular carcinoma with tumor growth in the inferior vena cava as far as in the right atrium were presented.

Selective celiac and hepatic arteriography demonstrated so-called "thread and streaks" sign and its equivalent from the hepatic vein to the right atrium running through the inferior vena cava.

Inferior vena cavography and ultrasoundcardiography were also demonstrated the tumor growth in the right atrium in one case.

Autopsy findings confirmed the diagnosis. In case 2, coagulofibrinolytic examination revealed consumption of coagulation factors (fibrinogen, platelets) and increased level of serum FDP.

* The Second Department of Medicine, Kurume University School of Medicine (Kurume)

** The First Department of Pathology, Kurume University School of Medicine (Kurume) 